\title{
Deinococcus yunweiensis sp. nov., a gamma- and UV-radiation-resistant bacterium from China
}

Correspondence

Wen-Jun Li

wjli@ynu.edu.cn

\author{
Yu-Qin Zhang, ${ }_{1,2}+$ Cheng-Hang Sun, ${ }^{1} \uparrow$ Wen-Jun Li, ${ }^{1,2}$ Li-Yan Yu, ${ }_{1}^{1}$ \\ Jian-Qin Zhou, ${ }^{1}$ Yue-Oin Zhang, ${ }^{1}$ Li-Hua $\mathrm{Xu}^{2}$ and Cheng-Lin Jiang ${ }^{2}$ \\ ${ }^{1}$ Institute of Medicinal Biotechnology, Chinese Academy of Medical Sciences \& Peking Union \\ Medical College, Beijing 100050, People's Republic of China \\ ${ }^{2}$ Laboratory for Conservation and Utilization of Bio-Resources, Yunnan Institute of Microbiology, \\ Yunnan University, Kunming, Yunnan, 650091, People's Republic of China
}

\begin{abstract}
A Gram-negative, non-spore-forming, non-motile, rod-shaped, red-pigmented strain, designated YIM $007^{\top}$, was found as a contaminant on an agar plate in the laboratory of Yunnan Institute of Microbiology, China. The optimum growth $\mathrm{pH}$ and temperature for the isolate were 7.0-7.5 and $30{ }^{\circ} \mathrm{C}$, respectively. The predominant respiratory quinone was MK-8. The polar lipid profile consisted mainly of various unknown phosphoglycolipids and glycolipids. The major cellular fatty acids were $\mathrm{C}_{16: 1} \omega 7 c, \mathrm{C}_{16: 0}, \mathrm{C}_{17: 0}$ and $\mathrm{C}_{17: 1} \omega 8 \mathrm{c}$. L-Ornithine was detected in its peptidoglycan. The DNA G +C content was 64.1 mol\%. Phylogenetic analysis based on 16S rRNA gene sequences indicated that strain YIM $007^{\top}$ showed 16S rRNA gene sequence similarity levels of 86.8-92.1\% to the other described Deinococcus species. Based on the high 16S rRNA gene sequence divergence and phenotypic differences, it is proposed that the unknown strain should be classified as a novel species in the genus Deinococcus with the name Deinococcus yunweiensis

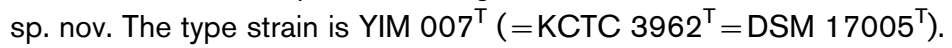

The members of the genus Deinococcus are non-sporeforming, non-motile, coccoid or rod-shaped cells that exhibit a remarkable capacity to resist the lethal effects of ionizing radiation (Minton, 1994; Moseley, 1983; Smith et al., 1992). The colony colour of most members of this genus is bright red, orange or light pink and the surface of the colonies is usually dry with pleats. At the time of writing, the genus Deinococcus comprises 20 species with validly published names (Suresh et al., 2004; Ferreira et al., 1997; Rainey et al., 1997; Brooks \& Murray, 1981; de Groot et al., 2005; Rainey et al., 2005; Lai et al., 2006), including 11 recently named species, Deinococcus deserti, D. ficus, D. hohokamensis, D. navajonensis, D. hopiensis, D. apachensis, D. maricopensis, D. pimensis, D. yavapaiensis, D. papagonensis and D. sonorensis (de Groot et al., 2005; Rainey et al., 2005; Lai et al., 2006). Of these 20 species, which were isolated from a wide range of environments, Deinococcus radiodurans, the type species of this genus, has been studied most extensively to elucidate the mechanisms of radiationresistance, and it has been determined that the radioresistance of this species is a direct result of its ability to repair efficiently the DNA damage generated during

TThese authors contributed equally to this work.

The GenBank/EMBL/DDBJ accession number for the $16 \mathrm{~S}$ rRNA gene sequence of strain YIM $007^{\top}$ is DQ344634.

Fatty acid profiles of strain YIM $007^{\top}$ and related strains are available as supplementary material in IJSEM Online. irradiation (Smith et al., 1992; Minton, 1994; Mattimore \& Battista, 1996; Battista, 1997; Battista et al., 1999). In this paper, we report the results of a polyphasic study of another hitherto-unknown gamma- and UV-radiation-resistant strain, designated YIM $007^{\mathrm{T}}$, which was found on a contaminated plate in our laboratory.

A red-pigmented contaminant was found on a yeast extractmalt extract agar plate $[4.0 \%$ yeast extract, $10.0 \%$ malt extract, $4.0 \%$ glucose, $2.0 \%$ agar; ISP 2 medium (Shirling \& Gottlieb, 1966)] with a bacterial culture at $28^{\circ} \mathrm{C}$ for about 2 weeks. It was then picked and serially diluted on ISP 2 agar plates. The purified strain, designed YIM $007^{\mathrm{T}}$, was maintained on ISP 2 agar slants at $4{ }^{\circ} \mathrm{C}$ and as a $20 \%(w / v)$ glycerol suspension at $-20^{\circ} \mathrm{C}$. Biomass for chemical and molecular studies was obtained by cultivation using ISP 2 broth or trypticase soy broth (Difco) $\left(30^{\circ} \mathrm{C}, 5\right.$ days, 150 r.p.m.).

Morphology and motility of cells grown for $12-48 \mathrm{~h}$ on ISP 2 agar medium were examined by light microscopy (model BH 2; Olympus) and using a Hitachi H-800 transmission electron microscope (TEM). For TEM observation, cells were negatively stained with $1 \%(\mathrm{w} / \mathrm{v})$ phosphotungstic acid after air-drying. Motility and flagella observation was performed using semi-solid agar and the staining method of Leifson (1960). Gram staining was carried out using the standard Gram reaction (Gram, 1884). Growth at different temperatures and $\mathrm{pH}$ was investigated as described by $\mathrm{Xu}$ 
et al. (2005), but using ISP 2 as the basic medium. Tolerance to $\mathrm{NaCl}(0.5,1,3,7,10,13$ and $15 \%)$ was also tested using ISP 2 medium. Metabolic properties were determined using API ID 32 E and API 32 GN test kits (bioMérieux) according to the manufacturer's instructions. Other physiological and biochemical tests were performed as described previously (Li et al., 2004).

To determine the tolerance of the isolate to UV radiation, the cultures were grown in the appropriate liquid medium to the exponential phase. The cells were recovered by centrifugation, washed with $0.067 \mathrm{M}$ potassium phosphate buffer at $\mathrm{pH} 7.0$ and then diluted serially, and $0.1 \mathrm{ml}$ was spread on ISP 2 agar plates (with their lids open) and then exposed to UV light at a distance of $30 \mathrm{~cm}$ from a UV source for the required dose and were then incubated at $30^{\circ} \mathrm{C}$ for 14 days. For the gamma-radiation-resistance determination, cells were prepared as above and then exposed at room temperature to gamma radiation from a cobalt-60 source at doses of 1 and $8 \mathrm{kGy} \mathrm{h}^{-1}$. After exposure to $0.1,3,5,9,10$ and $20 \mathrm{kGy}$, suspensions were diluted in triplicate on the appropriate solid medium. Growth after 15 days was scored as positive or negative in comparison to an unirradiated control. At the same time, D. radiodurans AS $1.633^{\mathrm{T}}$ and Escherichia coli DH5 $\alpha$ (both from the China General Microbiological Culture Collection Center, Beijing) were tested as positive and negative controls. Relative survival was determined by comparing with unirradiated cultures.

Purified peptidoglycan was prepared and analysed by the method of Schleifer \& Kandler (1972). The respiratory quinone was isolated using the methods of Minnikin et al. (1984) and separated by HPLC (Kroppenstedt, 1982). Analysis of the cellular fatty acid pattern followed described methods (Miller, 1982) using the MIDI system (Microbial ID, Inc.). Polar lipids were extracted and analysed by twodimensional TLC according to Tindall (1990). The DNA base composition of strain YIM $007^{\mathrm{T}}$ was determined by using the thermal denaturation method (Marmur \& Doty, 1962).

Extraction and amplification of genomic DNA for 16S rRNA gene sequence analysis were carried out as described by $\mathrm{Xu}$ et al. (2003). Multiple alignments with sequences of a broad selection of related species and calculations of levels of sequence similarity were carried out using CLUSTAL $\mathrm{X}$ (Thompson et al., 1997). A phylogenetic tree (Fig. 1) was reconstructed using the neighbour-joining method of Saitou \& Nei (1987) from $K_{\text {nuc }}$ values (Kimura, 1980, 1983). The topology of the phylogenetic tree was evaluated by the bootstrap resampling method of Felsenstein (1985) with 1000 replicates.

The cells of strain YIM $007^{\mathrm{T}}$ were aerobic, non-sporeforming, non-motile rods. Cells of Deinococcus grandis, Deinococcus indicus and $D$. deserti are also rod-shaped (Suresh et al., 2004; de Groot et al., 2005), whereas those of all other members of the genus are spherical (Rainey et al., 1997; Hirsch et al., 2004). As with cells of D. indicus, D.

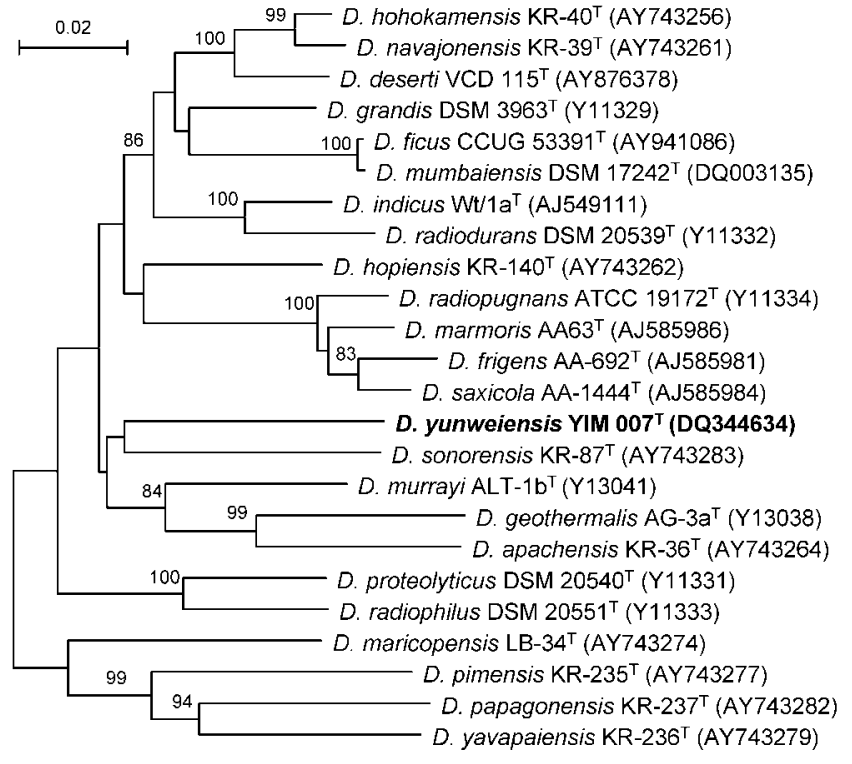

Fig. 1. Phylogenetic dendrogram obtained by distance-matrix analysis of $16 \mathrm{~S}$ rRNA gene sequences, showing the position of strain $\mathrm{YIM} 007^{\top}$ among its phylogenetic neighbours. Numbers on branch nodes are bootstrap values (percentages of 1000 resamplings; only values $>70 \%$ are given). The sequence of Thermus aquaticus YT-1 (GenBank accession no. L09663) was used as the root (not shown). Bar, $2 \%$ sequence divergence.

grandis and D. deserti, strain YIM $007^{\mathrm{T}}$ stained Gramnegative, whereas those of other Deinococcus species stain Gram-positive (Suresh et al., 2004; Hirsch et al., 2004). Colonies of strain YIM $007^{\mathrm{T}}$ were red, circular, shining and opaque on most agar media tested. The temperature range for growth was $10-50{ }^{\circ} \mathrm{C}$, with optimum growth at $30^{\circ} \mathrm{C}$. The $\mathrm{pH}$ range for growth was 6.0-9.0, with optimum growth occurring between $\mathrm{pH} 7.0$ and 7.5. The other physiological and biochemical properties of strain YIM $007^{\mathrm{T}}$ are listed in Table 1 or in the species description.

The survival rate of cultures of strain YIM $007^{\mathrm{T}}$ after exposure to increasing doses of gamma and UV radiation was analysed in comparison with $D$. radiodurans AS $1.633^{\mathrm{T}}$ and E. coli $\mathrm{DH} 5 \alpha$. There was no growth for E. coli DH5 $\alpha$ at a dose of $3.0 \mathrm{kGy}$ gamma radiation, whereas almost no decrease in survival was observed for strains $D$. radiodurans AS $1.633^{\mathrm{T}}$ and YIM $007^{\mathrm{T}}$. At $16.0 \mathrm{kGy}$ gamma radiation, there was still growth for D. radiodurans AS $1.633^{\mathrm{T}}$ and YIM $007^{\mathrm{T}}$. As for UV radiation tolerance, the lethal dose of UV radiation for E. coli $\mathrm{DH} 5 \alpha$ was $30 \mathrm{~J} \mathrm{~m}^{-2}$, whereas strains YIM $007^{\mathrm{T}}$ and $D$. radiodurans AS $1.633^{\mathrm{T}}$ could grow at the highest dose of $624 \mathrm{~J} \mathrm{~m}^{-2}$.

The peptidoglycan of strain YIM $007^{\mathrm{T}}$ contained Lornithine. The predominant respiratory quinone was detected as MK-8. The major fatty acids were monounsaturated and straight-chain saturated fatty acids, such as 
Table 1. Properties of strain YIM $007^{\top}$ useful for differentiation from selected species of the genus Deinococcus

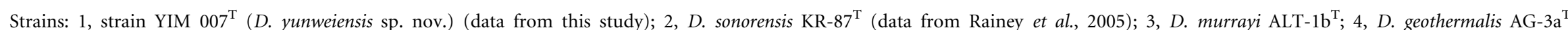
(data in columns 3 and 4 from Ferreira et al., 1997); 5, D. apachensis KR-36 ${ }^{\mathrm{T}}$; 6, D. hopiensis KR-140 ${ }^{\mathrm{T}}$; , D. radiodurans ATCC 13939 ${ }^{\mathrm{T}}$ (data in columns 5-7 from Rainey et al., 2005). + , Positive; -, negative; ND, no data available.

\begin{tabular}{|c|c|c|c|c|c|c|c|}
\hline Characteristic & 1 & 2 & 3 & 4 & 5 & 6 & 7 \\
\hline Morphology & Rod & $\begin{array}{l}\text { Spherical or } \\
\text { short rod }\end{array}$ & Spherical & Spherical & Spherical & Spherical & Spherical \\
\hline Gram stain & Negative & Positive & Positive & Positive & Positive & Positive & Positive \\
\hline Motility & - & - & - & - & + & - & - \\
\hline \multicolumn{8}{|l|}{$\begin{array}{l}\text { Temperature for } \\
\text { growth }\left({ }^{\circ} \mathrm{C}\right)\end{array}$} \\
\hline Range & $10-50$ & $\mathrm{ND}$ & $30-52.5$ & $30-55$ & $\mathrm{ND}$ & ND & ND \\
\hline Optimum & 30 & 30 & 47 & 47 & 30 & 30 & 30 \\
\hline \multicolumn{8}{|l|}{$\mathrm{pH}$ for growth } \\
\hline Range & $6.0-9.0$ & ND & $5.0-10.5$ & $4.0-9.0$ & ND & ND & ND \\
\hline Optimum & $7.0-7.5$ & $\mathrm{ND}$ & 8.0 & 6.5 & $\mathrm{ND}$ & $\mathrm{ND}$ & $\mathrm{ND}$ \\
\hline \multicolumn{8}{|l|}{ Carbon utilization } \\
\hline Rhamnose & + & + & - & + & + & + & - \\
\hline Ribose & - & + & - & ND & - & + & + \\
\hline Trehalose & - & + & + & + & + & + & + \\
\hline Mannitol & + & $\mathrm{ND}$ & - & + & ND & ND & ND \\
\hline D-Melibiose & + & + & - & - & ND & ND & ND \\
\hline Sorbitol & + & ND & - & + & ND & $\mathrm{ND}$ & $\mathrm{ND}$ \\
\hline L-Arabinose & + & + & - & - & + & + & - \\
\hline $\begin{array}{l}\text { Major fatty acids } \\
(>10 \%)\end{array}$ & $\begin{array}{c}16: 1 \omega 7 c(27.74 \%) \\
16: 0(26.03 \%) \\
17: 0(13.43 \%)\end{array}$ & $\begin{array}{c}15: 1 \omega 6 c(12.7 \%) ; \\
15: 0(10.3 \%) ; \\
16: 0 \text { iso }(12.5 \%) ; \\
16: 1 \omega 7 c(13.1 \%)\end{array}$ & $\begin{array}{c}17: 1 \omega 9 c \text { iso }(19.9 \%) ; \\
17: 0 \text { iso }(11.6 \%) ; \\
17: 0(10.4 \%)\end{array}$ & $\begin{array}{c}15: 0 \text { iso }(24.8 \%) ; \\
17: 0 \text { iso }(35.3 \%)\end{array}$ & $\begin{array}{l}15: 0 \text { iso }(11.2 \%) \text {; } \\
16: 0 \text { iso }(10.5 \%) \text {; } \\
16: 1 \omega 7 c(10.6 \%) \text {; } \\
17: 0 \text { iso }(10.8 \%)\end{array}$ & $\begin{array}{c}16: 1 \omega 7 c(51.1 \%) \\
16: 0(13.6 \%)\end{array}$ & $\begin{array}{c}16: 1 \omega 7 c(39.9 \%) \\
16: 0(14.1 \%) ; \\
17: 1 \omega 8 c(11.8 \%)\end{array}$ \\
\hline $\begin{array}{l}\text { DNA G }+ \text { C } \\
\text { content }(\mathrm{mol} \%)\end{array}$ & 64.1 & 70.3 & 69.9 & 65.9 & 68.5 & 66.2 & 67.0 \\
\hline Source & Contaminated plate & Desert soil & Hot spring & Hot spring & Desert soil & Desert soil & $\begin{array}{c}\text { Ground pork } \\
\text { and beef }\end{array}$ \\
\hline
\end{tabular}


$\mathrm{C}_{16: 1} \omega 7 c, \mathrm{C}_{16: 0}, \mathrm{C}_{17: 0}$ and $\mathrm{C}_{17: 1} \omega 8 c$, which were also predominant in most other Deinococcus species (see Supplementary Table S1 available in IJSEM Online). Specifically, for the new isolate YIM $007^{\mathrm{T}}$, relative amounts of some straight-chain saturated components, such as $\mathrm{C}_{16 \text { : } 0}$, $\mathrm{C}_{17: 0}, \mathrm{C}_{18: 0}$, were higher than in any other described Deinococcus species (Supplementary Table S1).

The results of two-dimensional TLC analysis of polar lipids extracted from $D$. radiodurans AS $1.633^{\mathrm{T}}$ and strain YIM $007^{\mathrm{T}}$ are shown in Fig. 2. Based on their staining behaviour, the polar lipid profiles of the two strains consisted of various unknown phosphoglycolipids (three in total) and glycolipids (five in total), and an unknown phospholipid and an unknown aminophospholipid were also detected. Polar lipid profiles of both strains were dominated by phosphoglycolipids, which is consistent with previously reported

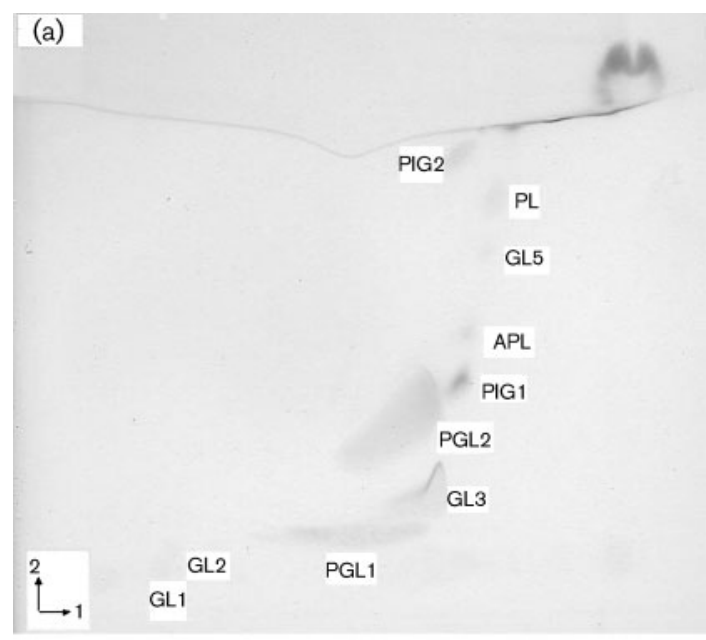

(b)

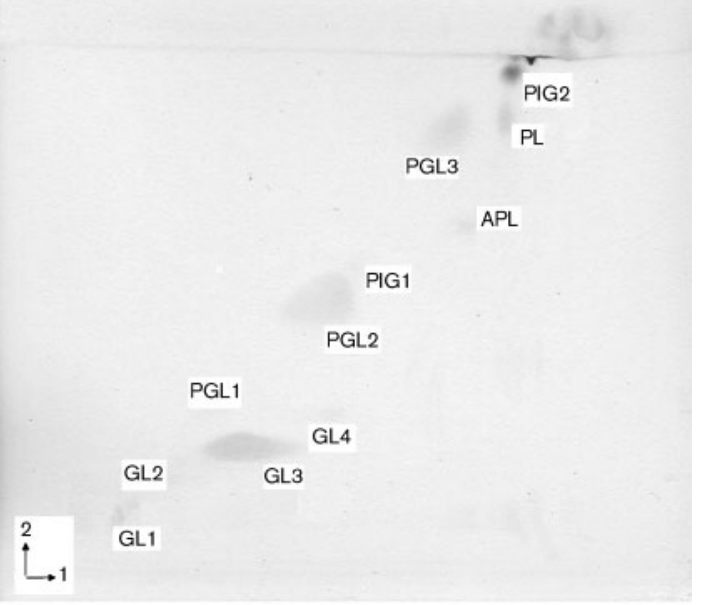

Fig. 2. Two-dimensional TLC of polar lipids of $D$. radiodurans AS $1.633^{\top}$ (a) and isolate YIM $007^{\top}$ (b). GL1-GL5, Unidentified glycolipids; PGL1-PGL3, unidentified phosphoglycolipids; PL, unidentified phospholipids; APL, unidentified aminophospholipid; PIG1 and PIG2, pigments. results for some Deinococcus species (Thompson et al., 1980; Counsell \& Murray, 1986; Embley et al., 1987). D. radiodurans AS $1.633^{\mathrm{T}}$ exhibited an unknown glycolipid component (GL5) and a relatively larger amount of unknown phosphoglycolipids PGL1 and PGL2, distinguishing it from YIM $007^{\mathrm{T}}$. Strain YIM $007^{\mathrm{T}}$ showed an unknown phosphoglycolipid (PGL3) that was not detected in $D$. radiodurans AS $1.633^{\mathrm{T}}$. The chromatographic behaviour of the polar lipids GL1-GL4, PGL1, PGL2 and PGL3 of strain YIM $007^{\mathrm{T}}$ was similar to the polar lipid spots GL1GL4, PGL1, PGL2 and PGL4 reported for D. ficus (Lai et al., 2006) and the polar lipids reported for Deinococcus radiophilus D16 and Deinococcus radiopugnans D17 (Embley et al., 1987). The presence of these lipids in extracts of strain YIM $007^{\mathrm{T}}$ confirms its assignment to the genus Deinococcus.

Comparison of the almost-complete 16S rRNA gene sequence (1459 bp) of strain YIM $007^{\mathrm{T}}$ with homologous sequences of a wide range of related type strains revealed that strain YIM $007^{\mathrm{T}}$ showed $16 \mathrm{~S}$ rRNA gene sequence similarity levels of $86.8-92.1 \%$ to the other described Deinococcus species. A distance matrix dendrogram is shown in Fig. 1. In the dendrogram, strain YIM $007^{\mathrm{T}}$ is encompassed by the major branch of the genus Deinococcus. The DNA G $+\mathrm{C}$ content was determined to be $64.1 \mathrm{~mol} \%$.

The results of $16 \mathrm{~S}$ rRNA gene sequence comparison together with chemotaxonomic data clearly demonstrate that strain YIM $007^{\mathrm{T}}$ is a member of the genus Deinococcus. However, strain YIM $007^{\mathrm{T}}$ forms a separate lineage within the genus (Fig. 1). Additionally, strain YIM $007^{\mathrm{T}}$ differs from some other Deinococcus species with validly published names in some phenotypic characteristics (Table 1). Therefore, based on the above phenotypic and genotypic data, it is proposed that strain YIM $007^{\mathrm{T}}$ represents a novel species of the genus Deinococcus, for which the name Deinococcus yunweiensis sp. nov. is proposed.

\section{Description of Deinococcus yunweiensis sp. nov.}

Deinococcus yunweiensis (yun.wei.en'sis. N.L. masc. adj. yunweiensis pertaining to Yunwei, an abbreviation of the Chinese name of Yunnan Institute of Microbiology, China, where the type strain was isolated).

Aerobic, Gram-negative, non-spore-forming, non-motile rods. The colony colour on most tested media is reddish. Colonies are circular, opaque and approximately 1.5$2.8 \mathrm{~mm}$ in diameter after incubation on ISP 2 medium for $24 \mathrm{~h}$ at $30^{\circ} \mathrm{C}$. The optimum growth $\mathrm{pH}, \mathrm{NaCl}$ concentration and temperature are respectively $\mathrm{pH} 7.0-7.5,0-1 \%$ and $30{ }^{\circ} \mathrm{C}$. Resistant to gamma (>16 kGy) and UV $\left(>624 \mathrm{~J} \mathrm{~m}^{-2}\right)$ irradiation. Catalase and oxidase reactions are positive. Casein is decomposed, while starch and Tween 80 are not decomposed. Positive for urease, lipase, $\alpha$-maltosidase, $\beta$-glucuronidase, $\alpha$-galactosidase, $N$-acetylglucosaminidase, $\beta$-glucosidase, lysine decarboxylase, 
gelatin liquefaction, methyl red test and Tween 20 esterase, while negative for ornithine decarboxylase, arginine dihydrolase and nitrate reduction. Glucose, rhamnose, sucrose, maltose, malonate, mannitol, salicin, D-melibiose, sorbitol, $\mathrm{L}$-arabinose and galacturonate can be utilized as sole carbon sources. The peptidoglycan contains L-ornithine. The predominant respiratory quinone is MK-8. The polar lipid profile consists mainly of various unknown phosphoglycolipids and glycolipids. The cellular fatty acids are $\mathrm{C}_{16: 1} \omega 7 c(27.7 \%), \mathrm{C}_{16: 0}(26.0 \%), \mathrm{C}_{17: 0}(13.4 \%), \mathrm{C}_{17: 1} \omega 8 c$ (9.4\%), $\mathrm{C}_{18: 0}(5.0 \%)$ and small amounts of $\mathrm{i}-\mathrm{C}_{11: 0}(0.5 \%)$, $\mathrm{C}_{12: 0}(0.6 \%), \mathrm{i}-\mathrm{C}_{13: 0}(1.0 \%), \mathrm{C}_{15: 1} \omega 6 c(0.4 \%), \mathrm{C}_{15: 0}$ $(1.8 \%), \quad \mathrm{C}_{16: 1} \omega 9 c \quad(0.8 \%), \quad \mathrm{i}-\mathrm{C}_{17: 0} \quad(1.4 \%), \mathrm{C}_{17: 1} \omega 6 c$ $(1.4 \%), \quad \mathrm{i}-\mathrm{C}_{17: 1} \omega 9 c \quad(1.4 \%), \quad \mathrm{C}_{18: 1} \omega 7 c \quad(2.8 \%) \quad$ and $\mathrm{C}_{18: 1} \omega 9 \mathrm{c}(4.1 \%)$. The DNA G $+\mathrm{C}$ content of the type strain is $64.1 \mathrm{~mol} \%$.

The type strain is strain YIM $007^{\mathrm{T}}\left(=\mathrm{DSM} 17005^{\mathrm{T}}=\mathrm{KCTC}\right.$ $\left.3962^{\mathrm{T}}\right)$.

\section{Acknowledgements}

This research was supported by the National Basic Research Program of China (project no. 2004CB719601), the National Natural Science Foundation of China (project nos 30240005 and 3060001) and the Yunnan Provincial Natural Science Foundation (project no. 2004 C0002Q); W.-J. L. was also supported by the Program for New Century Excellent Talent in University (NCET).

\section{References}

Battista, J. R. (1997). Against all odds: the survival strategies of Deinococcus radiodurans. Annu Rev Microbiol 51, 203-224.

Battista, J. R., Earl, A. M. \& Park, M. J. (1999). Why is Deinococcus radiodurans so resistant to ionizing radiation? Trends Microbiol 7 , 362-365.

Brooks, B. W. \& Murray, R. G. E. (1981). Nomenclature for "Micrococcus radiodurans" and other radiation-resistant cocci: Deinococcaceae fam. nov. and Deinococcus gen. nov., including five species. Int J Syst Bacteriol 31, 353-360.

Counsell, T. J. \& Murray, R. G. E. (1986). Polar lipid profiles of the genus Deinococcus. Int J Syst Bacteriol 36, 202-206.

de Groot, A., Chapon, V., Servant, P., Christen, R., Fischer-Le Saux, M., Sommer, S. \& Heulin, T. (2005). Deinococcus deserti sp. nov., a gamma-radiation-tolerant bacterium isolated from the Sahara Desert. Int J Syst Evol Microbiol 55, 2441-2446.

Embley, T. M., O’Donnell, A. G., Watt, R. \& Rostron, J. (1987). Lipid and cell wall amino acid composition in the classification of members of the genus Deinococcus. Syst Appl Microbiol 10, 20-27.

Felsenstein, J. (1985). Conference limits on phylogenies: an approach using the bootstrap. Evolution 39, 783-789.

Ferreira, A. C., Nobre, M. F., Rainey, F. A., Silva, M. T., Wait, R., Burghardt, J., Chung, A. P. \& da Costa, M. S. (1997). Deinococcus geothermalis sp. nov. and Deinococcus murrayi sp. nov., two extremely radiation-resistant and slightly thermophilic species from hot springs. Int J Syst Bacteriol 47, 939-947.

Gram, H. C. (1884). Über die isolierte Färbung der Schizomyceten in Schnitt- und Trockenpräparaten. Fortschr Med 2, 185-189 (in German).
Hirsch, P., Gallikowski, C. A., Siebert, J., Peissl, K., Kroppenstedt, R. M., Schumann, P., Stackebrandt, E. \& Anderson, R. (2004). Deinococcus frigens sp. nov., Deinococcus saxicola sp. nov., and Deinococcus marmoris sp. nov., low temperature and draughttolerating, UV-resistant bacteria from continental Antarctica. Syst Appl Microbiol 27, 636-645.

Kimura, M. (1980). A simple method for estimating evolutionary rates of base substitutions through comparative studies of nucleotide sequence. J Mol Evol 16, 111-120.

Kimura, M. (1983). The Neutral Theory of Molecular Evolution. Cambridge: Cambridge University Press.

Kroppenstedt, R. M. (1982). Separation of bacterial menaquinones by HPLC using reverse phase (RP 18) and a silver loaded ion exchanger as stationary phases. J Liq Chromatogr 5, 2359-2387.

Lai, W. A., Kämpfer, P., Arun, A. B., Shen, F. T., Huber, B., Rekha, P. D. \& Young, C. C. (2006). Deinococcus ficus sp. nov., isolated from the rhizosphere of Ficus religiosa L. Int J Syst Evol Microbiol 56, 787-791.

Leifson, E. (1960). Atlas of Bacterial Flagellation. London: Academic Press.

Li, W.-J., Zhang, Y.-Q., Park, D.-J., Li, C.-T., Xu, L.-H., Kim, C.-J. \& Jiang, C.-L. (2004). Duganella violaceinigra sp. nov., a novel mesophilic bacterium isolated from forest soil. Int J Syst Evol Microbiol 54, 1811-1814.

Marmur, J. \& Doty, P. (1962). Determination of the base composition of deoxyribonucleic acid from its thermal denaturation temperature. J Mol Biol 5, 109-118.

Mattimore, V. \& Battista, J. R. (1996). Radioresistance of Deinococcus radiodurans: functions necessary to survive ionizing radiation are also necessary to survive prolonged desiccation. J Bacteriol 178, 633-637.

Miller, L. T. (1982). Single derivatization method for routine analysis of bacterial whole-cell, fatty acids methyl esters, including hydroxy acids. J Clin Microbiol 16, 584-586.

Minnikin, D. E., O'Donnell, A. G., Goodfellow, M., Alderson, G., Athalye, M., Schaal, A. \& Parlett, J. H. (1984). An integrated procedure for the extraction of isoprenoid quinones and polar lipids. J Microbiol Methods 2, 233-241.

Minton, K. W. (1994). DNA repair in the extremely radioresistant bacterium Deinococcus radiodurans. Mol Microbiol 13, 9-15.

Moseley, B. E. B. (1983). Photobiology and radiobiology of Micrococcus (Deinococcus) radiodurans. Photochem Photobiol Rev 7, 223-275.

Rainey, F. A., Nobre, M. F., Schumann, P., Stackebrandt, E. \& da Costa, M. S. (1997). Phylogenetic diversity of the deinococci as determined by $16 \mathrm{~S}$ ribosomal DNA sequence comparison. Int J Syst Bacteriol 47, 510-514.

Rainey, F. A., Ray, K., Ferreira, M., Gatz, B. Z., Nobre, M. F., Bagaley, D., Rash, B. A., Park, M.-J., Earl, A. M. \& other authors (2005). Extensive diversity of ionizing-radiation-resistant bacteria recovered from a Sonoran Desert soil and the description of nine new species of the genus Deinococcus obtained from a single soil sample. Appl Environ Microbiol 71, 5225-5235.

Saitou, N. \& Nei, M. (1987). The neighbor-joining method: a new method for reconstructing phylogenetic tree. Mol Biol Evol 4, 406-425.

Schleifer, K. H. \& Kandler, O. (1972). Peptidoglycan types of bacterial cell walls and their taxonomic implications. Bacteriol Rev 36, 407-477.

Shirling, E. B. \& Gottlieb, D. (1966). Methods for characterization of Streptomyces species. Int J Syst Bacteriol 16, 313-340.

Smith, M. D., Masters, C. I., \& Moseley, B. E. B. (1992). Molecular biology of radiation resistant bacteria. In Molecular Biology and 
Biotechnology of Extremophiles, pp. 258-280. Edited by R. A. Herbert \& R. J. Sharp. New York: Chapman \& Hall.

Suresh, K., Reddy, G. S. N., Sengupta, S. \& Shivaji, S. (2004). Deinococcus indicus sp. nov., an arsenic-resistant bacterium from an aquifer in West Bengal, India. Int J Syst Evol Microbiol 54, 457-461.

Thompson, B. G., Anderson, R. \& Murray, R. G. (1980). Unusual polar lipids of Micrococcus radiodurans strain Sark. Can J Microbiol 26, 1408-1411.

Thompson, J. D., Gibson, T. J., Plewniak, F., Jeanmougin, F. \& Higgins, D. G. (1997). The CLUSTAL $X$ windows interface: flexible strategies for multiple sequence alignment aided by quality analysis tools. Nucleic Acids Res 25, 4876-4882.

Tindall, B. J. (1990). Lipid composition of Halobacterium lacusprofundi. FEMS Microbiol Lett 66, 199-202.

Xu, P., Li, W. J., Xu, L. H. \& Jiang, C. L. (2003). A microwave-based method for genomic DNA extraction from actinomycetes. Microbiology (Beijing) 30, 82-84 (in Chinese).

Xu, P., Li, W.-J., Tang, S.-K., Zhang, Y.-O., Chen, G.-Z., Chen, H.-H., Xu, L.-H. \& Jiang, C.-L. (2005). Naxibacter alkalitolerans gen. nov., sp. nov., a novel member of the family 'Oxalobacteraceae' isolated from China. Int J Syst Evol Microbiol 55, 1149-1153. 